\title{
Selective media in the isolation of tubercle bacilli from tissues
}

\author{
D. A. Mitchison, B. W. Allen, And R. A. LAmbert \\ From the Department of Bacteriology, Royal Postgraduate Medical School, London
}

SYNOPSIS Direct culture on Lowenstein-Jensen slopes and on three media made selective for tubercle bacilli by the addition of four antibacterial agents was compared with guinea-pig inoculation on 490 tissue specimens. Tubercle bacilli were obtained from 15 specimens by culture and 14 by guinea-pig inoculation; only one specimen was positive by guinea-pig and not by culture. The most efficient culture medium was a selective 7 H11 slope. Routine guinea-pig inoculation has been replaced by a wider range of culture procedures.

Many laboratories continue to use guinea-pig inoculation as well as culture for the isolation of tubercle bacilli from material which can only be obtained on a single occasion from a patient, particularly tissues obtained at operation. Guineapig isolation is much more expensive than culture, but tissues are difficult to decontaminate with conventional acid or alkali treatment without killing some of the few bacilli that may be present. Decontamination could be avoided and the culture procedure simplified by using the selective medium, containing four antibacterial agents, recently described by Mitchison, Allen, Carrol, Dickinson, and Aber (1972). A comparison has therefore been made of various modifications of this selective medium and guinea-pig inoculation in isolating tubercle bacilli from tissues. Although the number of positive cultures obtained is small, the results are sufficiently encouraging to merit reporting.

\section{Materials and Methods}

\section{CULTURE MEDIA}

The media used were Lowenstein-Jensen slopes, without potato starch (Cruickshank, 1965), selective 7H11 oleic acid-albumin agar with malachite green (Bacto, 0838), selective liquid Kirchner medium with phenol red, but without penicillin (Oxoid, CM193). Selective media contained polymyxin B 200 units $/ \mathrm{ml}$, carbenicillin $100 \mu \mathrm{g} / \mathrm{ml}$, trimethroprim $10 \mu \mathrm{g} / \mathrm{ml}$, and amphotericin B $10 \mu \mathrm{g} / \mathrm{ml}$. All media were dispensed in screw-capped (universal) containers, the slopes in $5 \mathrm{ml}$ and the liquid medium in $10 \mathrm{ml}$ amounts.

Received for publication 21 September 1972.
TREATMENT OF SPECIMENS

Tissues were ground in polytetrafluorethylene grinders or chopped with scissors and then ground in a Griffiths tube to make $2 \mathrm{ml}$ suspension. A Lowenstein-Jensen (LJ) slope and a selective 7H11 (S7H11) slope were each inoculated with two $5 \mathrm{~mm}$ diameter loopfuls of this suspension. The remaining suspension was equally divided into two samples which were allocated at random for inoculation into the thigh muscle of a guinea-pig and for culture into two bottles of selective Kirchner medium (SK), one of which received $0.2 \mathrm{ml}$ (SK0.2) and the other about $0.8 \mathrm{ml}$ suspension (SK0.8). Cultures were incubated at $37^{\circ} \mathrm{C}$ without added $\mathrm{CO}_{2}$. The $\mathrm{LJ}$ and S7H11 slopes were read weekly for seven to eight weeks. The SK bottles were subcultured onto an LJ slope and a segment of a blood agar plate when suspicious microcolonies were visible or at the end of the seven- to eight-week incubation period. Lowenstein-Jensen subcultures were incubated for three weeks. The guinea-pigs were sacrificed six weeks after inoculation and the organs cultured if suspected of being tuberculous.

\section{Results}

All of the 490 tissues received during the 16-month period ending June 1972 were examined. The type of tissue, the number of specimens yielding tubercle bacilli in any culture, and the contamination rates are set out in table I. Of the 16 positive specimens, one yielded Mycobacterium bovis from the guineapig but was negative on culture and two were positive on culture but the guinea-pig died prematurely. One further specimen yielded $M$. bovis by culture 


\begin{tabular}{|c|c|c|c|c|c|c|c|}
\hline \multirow[t]{2}{*}{ Type of Specimen } & \multirow[t]{2}{*}{ Total Specimens } & \multicolumn{2}{|c|}{ Positive by Culture } & \multicolumn{2}{|c|}{ Positive by Guinea-pig } & \multicolumn{2}{|c|}{$\begin{array}{l}\text { Contaminated in any } \\
\text { Culture }\end{array}$} \\
\hline & & No. & $\%$ & No. & $\%$ & No. & $\%$ \\
\hline $\begin{array}{l}\text { Endometrial biopsy } \\
\text { Lymph gland } \\
\text { Liver biopsy } \\
\text { Other tissues }\end{array}$ & $\begin{array}{r}390 \\
38 \\
22 \\
40\end{array}$ & $\begin{array}{l}2 \\
8 \\
0 \\
5\end{array}$ & $\begin{array}{r}1 \\
22 \\
0 \\
12\end{array}$ & $\begin{array}{l}1 \\
8 \\
0 \\
5\end{array}$ & $\begin{array}{r}0 \\
22 \\
0 \\
12\end{array}$ & $\begin{array}{r}57 \\
1 \\
0 \\
9\end{array}$ & $\begin{array}{r}14 \\
3 \\
0 \\
22\end{array}$ \\
\hline Total & 490 & 15 & 3 & 14 & 3 & 67 & 14 \\
\hline
\end{tabular}

Table I Results of culture and guinea-pig inoculation according to type of specimen

and guinea-pig inoculation, the remaining positive cultures being $M$. tuberculosis.

The numbers of specimens positive, contaminated, or associated with non-tuberculous death of the guinea-pig are set out for each type of medium in table II. Selective 7H11 slopes yielded the most positive cultures. There was a suggestion that SK medium was less successful, especially those bottles that received the larger inoculum. LowensteinJensen slopes were least successful in isolation and were much more often contaminated. Only one $(0.2 \%)$ of the 490 specimens yielded contaminants in all cultures, whereas $50(10.2 \%)$ of the guinea-pigs died; most of the deaths occurred during a single two-month period and were more numerous than has been our usual experience.

\begin{tabular}{lcc}
\hline $\begin{array}{l}\text { Medium } \\
(\text { or Animal) }\end{array}$ & Positive & $\begin{array}{l}\text { Contaminated } \\
\text { (or Dead) }\end{array}$ \\
\cline { 2 - 3 } & No. & No. \\
\hline LJ & $9(1 \cdot 8 \%)^{1}$ & $59(12 \cdot 0 \%)$ \\
S7H11 & $12(2.4 \%)$ & $17(3.5 \%)$ \\
SK0.2 & $11(2 \cdot 2 \%)$ & $6(1 \cdot 2 \%)$ \\
SK0.8 & $7(1.4 \%)$ & $6 \quad(1 \cdot 2 \%)$ \\
Total cultures & $152(3 \cdot 1 \%)$ & $13(0.2 \%)$ \\
Guinea-pig & $14(2.9 \%)$ & $50(10 \cdot 2 \%)$ \\
\hline
\end{tabular}

Table II Isolation of tubercle bacilli and contamination rates (or non-tuberculous deaths) on the various culture media and by guinea-pig inoculation

${ }^{1}$ All percentages calculated from the total of 490 specimens 2Positive on any medium

${ }^{3}$ Contaminated on all media

Table III sets out, in a compact manner, the results of all possible comparisons of the isolation rates between pairs of media (or guinea-pig inoculation) after exclusion, for each comparison, of specimens which were contaminated in either medium or which led to non-tuberculous death of the guinea-pig. Thus, eight specimens were positive on $\mathrm{S7H} 11$ slopes but negative in SK0.8 medium, whereas none were positive in SK0.8 medium but negative on S7H11 slopes $(P<0.01)$. Guinea-pig inoculation yielded significantly more positive results than any of the cul-

\begin{tabular}{|c|c|c|c|c|c|}
\hline \multirow{2}{*}{$\begin{array}{l}\text { Negative on Column } \\
\text { Medium, Positive } \\
\text { on Row Medium }\end{array}$} & \multicolumn{5}{|c|}{$\begin{array}{l}\text { Positive on Column Medium, Negative on Row } \\
\text { Medium }\end{array}$} \\
\hline & $L J^{1}$ & $S 7 H I I$ & $S K O \cdot 2$ & $S K 0 \cdot 8$ & $G P$ \\
\hline $\begin{array}{l}\text { LJ } \\
\text { S7H11 } \\
\text { SK0·2 } \\
\text { SK0.8 } \\
\text { GP }\end{array}$ & $\begin{array}{l}- \\
0 \\
1 \\
2 \\
0\end{array}$ & $\begin{array}{l}2 \\
4 \\
8 \\
0\end{array}$ & $\begin{array}{l}2 \\
2 \\
4 \\
0\end{array}$ & $\begin{array}{l}0 \\
0 \\
1 \\
0\end{array}$ & $\begin{array}{l}4 \\
2 \\
5 \\
6 \\
-\end{array}$ \\
\hline
\end{tabular}

Table III Matrix of numbers of specimens positive on one medium (or animal) and negative on the other (specimens with guinea-pig death or medium contamination excluded from each comparison)

${ }^{1}$ Contrast attaining statistical significance $(P<0.05)$ indicated by figures in bold type.

ture media except S7H11 (P $<0.05$ for all four comparisons). The mean incubation periods for the nine cultures positive both on $\mathrm{LJ}$ and S7H11 medium were 4.2 weeks and $3 \cdot 9$ weeks, respectively $(P=0 \cdot 2)$.

\section{Discussion}

Only one specimen yielded a positive guinea-pig but negative cultures, and the strain was $M$. bovis. Furthermore, information due to non-tuberculous death of the guinea-pig was lost in $\mathbf{5 0}$ of the specimens, but in only one of the culture sets, so that the overall results of culture were slightly superior to those of guinea-pig inoculations. Little benefit was thus obtained by carrying out guinea-pig inoculation as well as culture. A similar conclusion was reached from a larger comparison of culture (after decontamination with acid) and guinea-pig inoculation by Marks (1972). As a result of these findings, we have changed our procedures for specimens other than sputum. Routine guinea-pig inoculations have been stopped, leading to a saving of at least $£ 1500$ in animals, a larger range of culture media is being inoculated, particularly those suitable for $M$. bovis, and specimens likely to be heavily contaminated are being treated with acid before culture.

The results with the S7H11 slope are encouraging, since it appeared to be the best of the culture media 
and was the only one to yield positive cultures in numbers similar to those from guinea-pigs, despite an inoculum of tissue suspension 50 times smaller. A slope of this medium could with benefit be included for all specimens likely to be lightly contaminated. Preliminary results of other comparisons suggest, however, that direct inoculation of centrifuge deposits of more heavily contaminated specimens, such as urines, yields an unacceptably high contamination rate.

The superiority of S7H11 slopes over selective Kirchner medium might have been due in part to the inhibitory effect of large inocula of tissue, a phenomenon often seen in the culture of tissues from experimental animals. It therefore seems preferable to divide the material to be cultured fairly evenly between the different media rather than putting a large remainder volume into a single liquid culture.

We are grateful to Mrs Anne Steward and Mr R. Shah for expert technical assistance.

\section{References}

Cruickshank, R. (1965). Medical Microbiology, 11th ed. Livingstone, Edinburgh.

Marks, J. (1972). Ending the routine guinea-pig test. Tubercle, 53, 3134.

Mitchison, D. A., Allen, B. W., Carrol, L., Dickinson, J. M. and Aber, V. R. (1972). A selective oleic acid albumin agar medium for tubercle bacilli. J. med. Microbiol., 5, 165-175.

\section{The March 1973 Issue}

\section{THE MARCH 1973 ISSUE CONTAINS THE FOLLOWING PAPERS}

Study of the pedigree of a patient with type III hyperlipoproteinaemia and sinking prebeta lipoprotein D. BALLANTYNE, JANET S. JUBB, H. G. MORGAN, AND T. D. V. LAWRIE

The antimycotic activity of 5-fluorocytosine R. J. HOLT AND THE LATE R. L. NEWMAN

Present significance of resistance to trimethoprim and sulphonamides in coliforms, Staphylococcus aureus and Streptococcus faecalis EVELYN L. LEWIS AND R. W. LACEY

A controlled trial of the use of dip slides in general practice for the diagnosis of urinary infection ROSALIND MASKELL

Selectagerm: A new approach to clinical bacteriology P. W. GREAVES

The relationship of the dilute whole blood lysis time to the fibrinolytic activity of blood: effect of change in plasma fibrinogen J. A. HICKMAN, I. C. GORDON-SMITH, P. F. WHITFIELD, AND S. J. GODFREY

Fine structural evidence for hormone secretion by the human thymus J. M. VETTERS AND R. F. MACADAM

The role of the mesangial cell in proliferative glomerulonephritis A. M. DAVISON, D. THOMSON, MARY K. MACDONALD, W. S. UTTLEY, AND J. S. ROBSON
Electron microscopic study of the distribution of the Australia antigen in individual sera of $\mathbf{5 0}$ serologically positive blood donors and two patients with serum hepatitis LINDA M. STANNARD, J. MOODIE, G. A. KEEN, AND A. KIPPS

Liver cell dysplasia: a premalignant condition P. P. ANTHONY, C. L. VOGEL, AND L. F. BARKER

The optical and electron microscopic determination of pulmonary asbestos fibre concentration and its relation to the human pathological reaction T. ASHCROFT AND A. G. HEPPLESTON

A guide to bullous lesions of the skin N. F. C. GANE

\section{Technical methods}

Simple economical anaerobiosis A. P. BARTON AND J. A. WINZAR

A simple lyophilizer for direct line sublimation R. KEITH FARRELL AND $S$. D. JOHNSTON

Screening for neurofibrillary tangles and argyrophilic plaques with Congo Red and polarized light MOLLIE I. STOKES AND RODERICK J. TRICKEY

Letter to the Editor

Book review

Copies are still available and may be obtained from the PUBLISHING MANAGER, BRITISH MEDICAL ASSOCIATION, TAVISTOCK SQUARE, LONDON, WC1H 9JR, price $£ 1.05$ 